\title{
Macbeth - The Danger of Passion, Power and Betrayal: A Psychoanalytic Perspective
}

\author{
Noga Levine Keini \\ Department of Social Work, Ashkelon Academic College, Ashkelon, Israel
}

Email address:

keini_e@walla.co.il

\section{To cite this article:}

Noga Levine Keini. Macbeth - The Danger of Passion, Power and Betrayal: A Psychoanalytic Perspective. Humanities and Social Sciences. Vol. 8, No. 6, 2020, pp. 191-199. doi: 10.11648/j.hss.20200806.14

Received: November 30, 2020; Accepted: December 23, 2020; Published: December 31, 2020

\begin{abstract}
Macbeth is a very popular play and is the shortest tragedy that Shakespeare wrote. The play was written between the years 1599 - 1606 and was performed worldwide in professional theatres. The play deals with the dangers of passion, power and betrayal among friends and as a morality play it presents the destructive power of evil. This evil is not necessarily particular to the characters but represents universal evil. The play transcends time and place and consequently is currently relevant. Psychoanalytic theory proposed by Sigmund Freud in the early 20th century and subsequently developed by his students and their successors, caused a dramatic change in understanding the drives underlying human behaviour and their effect on the life of the individual and society. In choosing the subject for the present article I have tried to combine two fields that are of particular interest to me: psychoanalytic theory, as developed by Freud and his successors; and classic literature. In the latter case, I opted for Shakespeare's Macbeth, a play that portrays exquisitely the intense struggle between mental forces in man, as well as the impact of these forces on behaviour and on the course pursued by individuals and society. This article does not purport to be a scientific analysis à la Sigmund Freud, but rather a treatment of the play as a metaphor for psychoanalytic structures and for the universal human drama in progress, as did Shakespeare himself, with messages that are relevant for contemporary society.
\end{abstract}

Keywords: Shakespeare, Mental Distress, Psychoanalytic Theory, Unconscious, Awareness

\section{Introduction}

Artists and culturists have gone to great lengths in describing human behaviour, in attempting to understand its origins, and in observing its impact on social events and processes. Manifestations of these efforts may be found in countless manuscripts, philosophical and scientific papers, and artistic works. For hundreds of years human behaviour was explained as the outcome of external forces, such as the will of God, supernatural influences and heavenly bodies. Even when attempts were made to trace behavioural phenomena to inner mental processes, the explanations remained ambiguous.

Psychoanalytic theory, proposed by Sigmund Freud in the early 20 th century and subsequently developed by his students and their successors, caused a dramatic change in understanding the drives underlying human behaviour and their effect on the life of the individual and society. The causes behind the human drama taking place on the stage of history, once obscure, were now explainable and understandable based on clear scientific principles [1].

In choosing the subject for the present article I have tried to combine two fields that are of particular interest to psychoanalytic theory, as developed by Freud and his successors; and classic literature. [11] In the latter case, I opted for Shakespeare's Macbeth, a play that portrays exquisitely the intense struggle between mental forces in man, as well as the impact of these forces on behaviour and on the course pursued by individuals and society.

I have tried to view the tragedy of the Scottish king living in the 11th century, as written by Shakespeare in the early 17 th century, in light of the fundamental concepts embodied in psychoanalytic theory from the 20th century [13]. The article does not purport to be a scientific analysis $\grave{a}$ la Sigmund Freud, but rather a treatment of the play as a metaphor for psychoanalytic structures and for the universal human drama in progress, as did Shakespeare himself, with messages that are relevant for contemporary society. 
Our search for material sources did not turn up any previous attempts at analyzing the play according to psychoanalytic theory. I have therefore based this article on well-known psychoanalytic materials and on the relevant theoretical literature.

\section{The Weird Sisters - Witches as Representative of the Id's Urges}

Macbeth opens with a scene showing three witches planning a meeting with Macbeth, the outcome of which is to be fateful for both the Kingdom of Scotland and the protagonist himself. The witches, bizarre and confusing, combine both feminine and masculine attributes, arousing wonderment and uneasiness:

"... what are these

So withered and so wild in their attire,

That look not like th' inhabitants $o^{\prime}$ th' Earth ...

You should be women,

And yet your beards forbid me to interpret

That you are so." (Act 1, Scene 3) [7].

The witches' speech too is filled with ambiguities, innuendoes and illogic:

Fair is foul, and foul is fair

Hover through the fog and filthy air." (Act 1, Scene 1)

Their behaviour renders their presence elusive, perplexing and ethereal:

Banquo: The earth hath bubbles, as the water has,

And these are of them. Whither are they vanished?

Macbeth: Into the air, and what seemed corporal

Melted, as breath into the wind..."(Act 1, Scene 3)

The witches' characteristics are reminiscent of unconscious id processes, as described by Freud and embodied in psychoanalytic theory. These processes represent the individual's latent desires, some of which are in opposition to ethical principles, as well as his instinctive urges, which are often out of sync with reality. The individual is not aware of them, but is nevertheless influenced by them in terms of his emotions and behaviour, and these in turn impact the path he chooses in life, or simply, his destiny [4].

Symbolically, Shakespeare chose to call the witches in his play the "weird sisters", a fact that could suggest the role of forces that are invisible to man during his lifetime and are not part of his awareness. As a product of the period in which belief in supernatural forces was rife - forces external to the individual but interacting with him and playing a crucial role in guiding him through life - Shakespeare chose to give corporal form to what Freud defined as the unconscious processes that lie deep within the personality: the id [4].

It is interesting that the first characters to appear on the stage in Macbeth are the weird sisters. This is in keeping with psychoanalytic theory, which refers to the primacy of the id forces in forging the individual's personality, as well as the fact that these forces constitute the basis for personality development and serve as the chief source of energy for building and maintaining its other parts: the ego and superego.

Despite their differences in perceiving the source and location of the unseen forces influencing the life and destiny of the individual, both Freud and Shakespeare emphasize their important, and at times even fateful (deterministic), impact on a person's actions and future, as seen in the words of Banquo, Macbeth's friend, and subsequently, his victim:

That, trusted home,

Might yet enkindle you unto the crown,

Besides the thane of Cawdor. But 'tis strange.

And oftentimes, to win us to our harm,

The instruments of darkness tell us truths,

Win us with honest trifles, to betray's

In deepest consequence"(Act 1, Scene 3)

For therapists who base their professional approach on the concepts of psychoanalytic theory, the role of the witches / weird sisters in the play may be seen to be an external representation that accords with the beliefs of the period vague, occult mental forces, at times alarmingly powerful, exerting an unconscious influence that determines to a great extent the path pursued by the individual in life. We regard the therapeutic efforts involved in raising these forces and their impacts to a level of awareness as constituting a basis for developing a meaningful process of treatment aimed at enhancing the individual's awareness of his life as well as his control over his conduct and destiny.

\section{Occult Ceremonies and Representation of the Inner Stranger}

An additional motif that is manifested in the figures of the weird sisters and their activities, as may be identified and defined based on psychoanalytic concepts, is the representation of the "inner stranger".

Numerous psychoanalysts have investigated coping methods adopted by individuals and social groups in the face of issues that jeopardize mental stability and arouse feelings of anxiety, tension, threat and rejection. These issues reside deep in the human soul, being complex and at times replete with contradictions and tensions due to the action of opposing mental forces. The tension created between the urgent desires of the id for immediate, unrestrained satisfaction of the most primitive needs, the adaptive action of the ego for preservation of life, and the stringent ethical requirements of the superego constitutes at times a major challenge for humans. One of the ways to ease tension and distress in such cases is use of the defence mechanism of projection, aimed at discharging onto an external entity the mental content threatening the individual and the group, thereby identifying it as something inimical instead of regarding it as part of the self [6].

Defensive projection results in the creation of an external representation of the inner stranger, who in the eyes of the individual and the group consists of "others" who are foreign and different from us in outward appearance, life span or religious belief. This process enables us to expose our 
threatening attributes and "deposit" them with some concrete stranger, thus replacing the inner conflict with an external one that is easier to bear [6].

To our understanding, the witches in Macbeth embody, among other things, the role of the stranger to which the audience and readers of Shakespeare's time could easily project the inner content threatening them. This is especially manifested in the description of the occult ceremonies held by the weird sisters, containing elements arousing revulsion and fear in the 17th century Christian:

Round about the cauldron go,

In the poisoned entrails throw...

Witches' mummy ...

Root of hemlock digged $i^{\prime}$ th' dark,

Liver of blaspheming Jew,

Gall of goat and slips of yew

Slivered in the moon's eclipse,

Nose of Turk and Tartar's lips,

Finger of birth-strangled babe

Ditch-delivered by a drab ...

Double, double toil and trouble,

Fire burn and cauldron bubble."(Act 4, Scene 1)

The human propensity for projecting outwards threatening mental content is no less relevant today than it was during Shakespeare's time. Though external representations of the inner stranger have changed somewhat since medieval times, the tendency to pin on to others disturbing, threatening parts of the self constitutes even today fertile ground for interpersonal and social conflicts. A psychodynamic understanding of these process could greatly help in developing a capacity for self-containment and containment of the other, thus allaying tensions in personal and social relations.

\section{The Murder of Good King Duncan as a Case of Patricide and a Manifestation of the Oedipus Complex}

An additional theme that emerges from the play - one that is principal to the plot - is the murder of King Duncan by the hand of Macbeth. We view this theme as a distillation of several motifs that are pertinent to the human experience, on the level of both the individual and society. In terms of the play's development, Duncan's murder constitutes a turning point in Macbeth's tragic destiny and the beginning of a downward spiral on the part of one who had earlier appeared so clearly to be heading in the direction of success and glory.

From the viewpoint of social messages, Duncan's murder by Macbeth symbolizes the crossing of a number of boundaries of major universal significance. Firstly, the act is powerful in introducing the motif of treason:

1) Macbeth is a beloved subject of Duncan's and his righthand man.

2) Macbeth and Duncan are related: the start of the play sees Duncan calling Macbeth $\mathcal{O}$ valiant cousin! Worthy gentleman!"
3) At the time of the murder Macbeth is entertaining Duncan at his castle and the king is confident of his host's concern for the safety of his guests.

Injury to a person who is a symbol of power is another motif that arises from Macbeth's "bloody deed", as defined by Dorothea Crook in her book Elements of Tragedy [5]. The act transforms the hero into a villain, resulting in his punishment and ultimate destruction, providing an important and powerful cathartic experience for the reader and audience. Harm has been caused to the king, the embodiment of social law and order, as well as the possessor of the fundamental tenets of judicial, ethical and social standards, and other exalted values that have been bestowed on him by the grace of God. He thus serves as God's agent, messenger and executor of His will on earth [5].

The role of a king has ever denoted unification, organization and discipline in all cultures and in all times. Such recognition is accorded the monarch in Judaism - the verse "In those days there was no king in Israel: every man did that which was right in his own eyes" (Judges 21:25) expresses the absence of an entity to maintain social order and values. Is it possible that the king's murder symbolizes regression and failure by the ego, in its role as a central organizing agent, in the face of urges and impulses that threaten the civilized individual? The king is also a father figure in the eyes of his subjects, father to the nation who has been entrusted with determining laws and punishing those who violate them. He is acting on behalf of God, who too fills the role of father according to His believers, as evidenced in the line "Our Father, Our King" recited by Jews during the period of the High Holydays.

In light of the above, it may be concluded that the murder of King Duncan by Macbeth serves as a motif for patricide, with all the significance of the Oedipal conflict as defined in psychoanalytic theory. Although the text does not reveal any sexual overtones in connection with the murder of the fatherking, it is clear that the murder is committed in order to remove an obstacle standing in Macbeth's way in his passion for power and control. And if we take into consideration that symbolically the king serves in the eyes of his subjects and in his own eyes as a father, while the nation over which he rules is regarded by its citizens as a mother, we can quite easily see how the Oedipus complex as defined by Freud finds expression in the act of murder [3].

The intensity of the mental tension, evoking the extreme fear existing in the Oedipal conflict, mostly suppressed and unconscious, can be identified in Macbeth's words:

This supernatural soliciting

Cannot be ill, cannot be good...

... why do I yield to that suggestion

Whose horrid image doth unfix my hair

And make my seated heart knock at my ribs,

Against the use of nature?...

My thought, whose murder yet is but fantastical,

Shakes so my single state of man

That function is smothered in surmise ..."(Act 1, Scene 3) 


\section{The Personality of Macbeth - From Valiant Warrior to Unbridled Tyrant}

As the protagonist in the tragedy, Macbeth is viewed by the reader as a complex figure who undergoes dramatic changes throughout the play. Macbeth is a Scottish nobleman, a relative of the King of Scotland, and one of the most skilful and courageous militarists in the country, having fought against the invading king of Norway and the rebels who had joined forces with him to overthrow Duncan. [12] Macbeth's valour is described to Duncan by an officer who participated in that battle:

...for brave Macbeth - well he deserves that name-

Disdaining fortune, with his brandished steel,

Which smoked with bloody execution,

Like valor's minion carved out his passage

Till he faced the slave;

Which ne'er shook hands, nor bade farewell to him,

Till he unseamed him from the nave to th' chops,

And fixed his head upon our battlements. "(Act 1, Scene 2)

For the above action and for his victory in the battle Macbeth has praise heaped on him by the king and others. The king bestows an additional thanehood on him, while also gifting him the estate belonging to another nobleman who had participated in the rebellion against the king. At first the plot appears to hold nothing but promise for the protagonist. This impression, however, is somewhat altered when the audience encounters Macbeth for the first time in person, when he gives voice to his experience on the day of the battle and ultimate victory:

So foul and fair a day I have not seen."

This statement echoes the voices of the witches in the first act, as they plan their meeting with Macbeth to inform him of their prophecy:

Fair is foul, and foul is fair ..."

The similarity between the two statements suggests the existence of a conceptual, and perhaps also emotional, relationship between the valiant warrior and the figures representing the forces of darkness and destruction even before they meet on the stage. [15] On observing the plot through the lens of psychoanalytic theory, it becomes evident that Macbeth is speaking in the tongue of id forces and that his inner world is replete with unresolved conflicts ("fair is foul") that occur concurrently.

This impression gains in intensity as the plot develops. On their first meeting with Macbeth, the weird sisters inform him that he is about to be made thane of Cawdor and subsequently even crowned king. Banquo, Macbeth's comrade in arms and in victory, who is present on this occasion, observes Macbeth's reaction:

Good sir, why do you start and seem to fear

Things that do sound so fair" (Act 1, Scene 3)

The text suggests that the idea of kingship is not foreign to Macbeth, and that the prophesy of the weird sisters falls as wild seed on fertile soil in his mind. Macbeth later hears that he is indeed to be made thane of Cawdor; thus the prophesies of the weird sisters and the latent desires in his heart are, from the psychoanalytic perspective, starting to be fulfilled:

Two truths are told,

As happy prologues to the swelling act

Of the imperial theme ..." (Act 1, Scene 3)

The audience now observes a process of development in the protagonist's emotional and cognitive state, in which his innermost desires and cravings for glory and power are beginning to fill his consciousness and dictate his moves. The audience is witness to the struggle taking place in Macbeth's mind as he thirsts for the crown and slowly yields to the urges of the id. His ego and superego, however, are still opposed to the idea of gaining command by immoral and dangerous means, such as rebellion or even murder:

If chance will have me king, why, chance may crown me

Without my stir."(Act 1, Scene 3)

As the plot develops, we see an intensification of the internal conflict taking place between Macbeth's impulses and the demands of logic and morality. The fact that these values are giving way to Macbeth's urges is seen in his following statement:

Stars, hide your fires;

Let not light see my black and deep desires.

The eye wink at the hand, yet let that be

Which the eye fears, when it is done, to see."(Act 1, Scene 4)

From the dynamic developing in Macbeth's mind we can see how the violent urges in his personality, which had hitherto been sublimated through his actions on the field of battle, are slowly losing their protective armour and are turning into uncontrollably destructive forces that are in opposition to all ethical mores and social conventions $[2,9]$.

The struggle between the opposing forces in Macbeth is decided by his interceding wife, Lady Macbeth. The letter her husband received informing him of the prophesy given by the weird sisters has ignited violent, destructive instincts in her and has whetted her appetite for power, with no thought given to the exigencies of reality and morality. Lady Macbeth is well aware of her husband's split, neurotic personality, and fears he will not be able to satisfy his greed because of the restraining influence of the ego and superego forces within him:

Glamis thou art, and Cawdor; and shalt be

What thou art promised. Yet do I fear thy nature;

It is too full o' th' milk of human kindness

To catch the nearest way: thou wouldst be great,

Art not without ambition, but without

The illness should attend it. What thou wouldst highly,

That wouldst thou holily; wouldst not play false,

And yet wouldst wrongly win." (Act 1, Scene 5)

Lady Macbeth thus decides to exert her influence on him in order to tip the scales in their favour by clinching their decision to satisfy their murderous appetite:

Hie thee hither,

That I may pour my spirits in thine ear

And chastise with the valor of my tongue

All that impedes thee from the golden round ..." (Act 1, Scene 5)

When Macbeth arrives at the castle his wife persuades him 
to fulfil his desire to seize the throne by murdering King Duncan, who is to be their guest in their home:

Your face, my thane, is as a book where men

May read strange matters. To beguile the time,

Look like the time. Bear welcome in your eye,

Your hand, your tongue. Look like th' innocent flower,

But be the serpent under 't...."(Act 1, Scene 5)

The audience witnesses the agonizing process that the tragic protagonist undergoes, during which the forces of the ego and the demands of the superego, which should be acting to restrain the non-adaptive impulses of the id, are weakening. Macbeth's ego ultimately succumbs to his instinctive impulses:

If it were done when 'tis done, then 'twere well

It were done quickly. If the assassination

Could trammel up the consequence, and catch

With his surcease success; that but this blow

Might be the be-all and the end-all here,

But here, upon this bank and shoal of time,

We'd jump the life to come..." (Act 1, Scene 7)

Led by his destructive id urges on the one hand, and assaulted by the moral principles of the superego on the other, Macbeth experiences extreme emotional upheaval in the moments prior to his committing the murder, manifested in the evocation of apocalyptic images:

Now o'er the one half-world

Nature seems dead, and wicked dreams abuse

The curtained sleep. Witchcraft celebrates

Pale Hecate's offerings, and withered murder,

Alarumed by his sentinel, the wolf,

Whose howl's his watch, thus with his stealthy pace,

With Tarquin's ravishing strides, towards his design

Moves like a ghost."(Act 2, Scene 1)

Duncan's murder is a shock to Macbeth's self, upsetting the little balance there is in his neurotic mind. He thus begins to display neurotic symptoms such as anxiety and severe emotional flooding:

How is 't with me when every noise appals me?

What hands are here? Ha! They pluck out mine eyes.

Will all great Neptune's ocean wash this blood

Clean from my hand? No, this my hand will rather

The multitudinous seas incarnadine,

Making the green one red."(Act 2, Scene 2)

On the one hand, he rues the deplorable act:

To know my deed, 'twere best not know myself."(Act 2,

Scene 2)

Had I but died an hour before this chance,

I had lived a blessèd time, for from this instant

There's nothing serious in mortality."(Act 2, Scene 3)

On the other hand, the mental dynamic no longer allows him to stop the destructive course of events. Macbeth senses a threat from his friend Banquo because Banquo's offspring are to inherit the throne from Macbeth according to the prophesy of the weird sisters, and also because Banquo's level-headed, healthy personality challenges Macbeth's damaged, unstable self:

To be thus is nothing,
But to be safely thus. Our fears in Banquo

Stick deep, and in his royalty of nature

Reigns that which would be feared. 'Tis much he dares,

And to that dauntless temper of his mind

He hath a wisdom that doth guide his valor

To act in safety. There is none but he

Whose being I do fear, and under him

My genius is rebuked ..."(Act 3, Scene 3)

Threat and fear propel Macbeth towards a decision to do away with Banquo and his son Fleance with the help of murderers recruited by him. He thus sinks lower into a whirlpool of destructive conduct while slowly losing control over matters, only to discover that his extreme acts, far from relieving him of his distress, are in fact exacerbating it:

"... both the worlds suffer,

Ere we will eat our meal in fear, and sleep

In the affliction of these terrible dreams

That shake us nightly. Better be with the dead,

Whom we, to gain our peace, have sent to peace,

Than on the torture of the mind to lie

In restless ecstasy. "(Act 3, Scene 2)

In light of the profound mental distress, increasingly acute neurotic symptoms, including insomnia, growing physical and mental stress, and despair experienced by Macbeth, he makes an attempt to involve his wife and receive some understanding and support from her. Lady Macbeth, however, is unable to show any empathy for his condition and responds by asking him to mobilize the primitive defence mechanisms of denial and suppression at his disposal:

These deeds must not be thought

After these ways. So, it will make us mad. "(Act 2, Scene 2)

On receiving no appropriate response to his distress and given its intensification, Macbeth's condition deteriorates even further. His ego crumbles under the pressure of the id's instinctive impulses on the one hand, and the moral demands of the superego on the other; the neurotic symptoms thus give way to a psychotic state, manifested in delusions. At a banquet prepared in his honour, Macbeth sees the bloodied figure of Banquo getting into Macbeth's chair - a mute admonishment for the murderous act:

Thou canst not say I did it. Never shake

Thy gory locks at me. (Act 3, Scene 4)

Macbeth's aberrant behaviour embarrasses the others, arousing suspicion among them and anger in his wife, who tries her best to cover it up. When Macbeth feels he is losing control over his emotions and conduct, he turns to the weird sisters who prophesied greatness for him in order to receive some signs that would afford him a sense of control and confidence. On meeting the weird sisters, Macbeth sees three visions, which may also, according to psychoanalytic concepts, be linked to psychotic phenomena - delusional sights and sounds that appear due to the collapse of the ego in the face of overwhelming pressure from the opposing forces of the id and superego. The visions inform Macbeth that he must beware of Macduff, another Scottish nobleman, lest he be bested by "a woman born", while assuring him at the same time that his reign will be secure until Birnam Wood, located 
at a distance of about $20 \mathrm{~km}$ from his castle, "marches to fight you." In the course of the third vision, Macbeth sees a row of future Scottish kings who resemble Banquo, murdered at his behest. The visions seen by Macbeth, with their contradictory messages, only intensify his confusion and distress. Encouraged by the two latest assurances, but concerned about the warning in the first vision, Macbeth decides to act mercilessly against any person who would threaten his rule. He sends murderers to kill Macduff's wife, children, his entire household and servants. Macduff himself is at the time in England, together with Malcolm, one of Duncan's sons. This desperate move symbolizes the final erosion of moral boundaries that still existed in Macbeth and a total loss of discretion with respect to his conduct:

The very firstlings of my heart shall be

The firstlings of my hand. And even now,

To crown my thoughts with acts, be it thought and done ..." (Act 4, Scene 1)

From that moment on, the tragic protagonist becomes an unrestrained, terror-stricken tyrant, who regards any act of violence as legitimate in ensuring his own supposed safety:

For mine own good,

All causes shall give way. I am in blood

Stepped in so far that, should I wade no more,

Returning were as tedious as go o'er."'Act 3, Scene 4)

In a fit of paranoia, terror and tyranny, Macbeth alienates himself from his surroundings, makes enemies of friends, and renders his subjects' lives miserable. Meanwhile, in England, King Edward is assembling an army led by Malcolm, the exiled prince of Scotland whose father, King Duncan, was murdered by Macbeth. Malcolm is joined by Macduff, who wishes to wreak vengeance on Macbeth for killing his family, as well as by other Scottish noblemen who are opposed to Macbeth. When Macbeth learns about the impending army, he gears up for battle, holding on blindly to the assurance of the weird sisters that his realm is secure as long as Birnam Wood stands firm and does not advance towards his castle, and that no person of "a woman born" (understood by him as being anyone at all) would be able to harm him. Nevertheless, Macbeth admits to himself that his aspiration for glory and adulation, achieved by gaining the throne, has not been fulfilled, even though he has attained his coveted status:

I have lived long enough. My way of life

Is fall'n into the sere, the yellow leaf,

And that which should accompany old age,

As honor, love, obedience, troops of friends,

I must not look to have, but, in their stead,

Curses, not loud but deep, mouth-honor, breath

Which the poor heart would fain deny and dare not."(Act 5, Scene 3)

In preparing for battle, Macbeth receives information that his wife has died. His mental condition and the dullness of sense that he has developed by living in constant fear and under a constant threat as a result of his violent actions do not allow him to express human empathy and sorrow over the loss of the person closest to him:

\section{She should have died hereafter.}

There would have been a time for such a word.

Tomorrow, and tomorrow, and tomorrow,

Creeps in this petty pace from day to day

To the last syllable of recorded time,

And all our yesterdays have lighted fools

The way to dusty death. Out, out, brief candle!"(Act 5, Scene 5)

Macbeth's words reflect a sense of meaninglessness in his existence and a devaluation of human life:

Life's but a walking shadow, a poor player

That struts and frets his hour upon the stage

And then is heard no more. It is a tale

Told by an idiot, full of sound and fury,

Signifying nothing. "(Act 5, Scene 5)

Adding to Macbeth's dissatisfaction with his life is the deep disappointment he feels on seeing the disintegration of the last vestige of faith that had offered him a sense of security - the belief in the assurance of the weird sisters. On their way to Macbeth's castle via Birnam Wood, soldiers under orders from Prince Malcolm chopped down the branches of trees in order to camouflage themselves and prevent the enemy from estimating their numbers. The army continues to march on to the castle, acting out, so to speak, the scenario of the wood approaching the castle and overwhelming it. In face-to-face combat that pits Macbeth against Macduff, Macbeth announces that he is immune to injury by any man, in accordance with the assurance he received in the vision he saw on meeting the witches. In reply, Macduff informs him that he "was from his mother's womb untimely ripped" (born by Caesarean section) and is therefore, strictly speaking, not of "a woman born." Thus is rung the death knell for the last bulwark that afforded Macbeth a sense of security and stability, symbolizing from the psychoanalytic viewpoint the breakdown of his false self. Macbeth's defence is no more.

Macbeth falls in battle and his severed head is brought to Prince Malcolm, who is crowned the new King of Scotland. This symbolic act, which recalls the scene at the start of the play in which Macbeth, the valiant warrior, sticks the head of the treacherous Macdonwald on the battlements, brings the plot full circle, with the triumph of moral justice and social order. The audience is now primed for experiencing a catharsis.

\section{Lady Macbeth - From Deadly Determination to Guilty Death}

The protagonist's wife, Lady Macbeth, plays an important role in the plot and is also interesting in terms of her mental condition and conduct in the context of psychoanalytic theory. The process Lady Macbeth undergoes is in a way the reverse of the course taken by her husband. No sooner did she receive information on the prophesy of kingship for Macbeth than she rallied to fulfil his megalomaniac aspirations, which coincided with her own. However, in 
contrast to Macbeth, who sets out on his murderous path towards the crown hesitatingly and ambivalently, his wife adopts the idea wholeheartedly: [8]

Come, you spirits

That tend on mortal thoughts, unsex me here,

And fill me from the crown to the toe top-full

Of direst cruelty. Make thick my blood.

Stop up the access and passage to remorse,

That no compunctious visitings of nature

Shake my fell purpose, nor keep peace between

The effect and it!'(Act 1, Scene 5)

Lady Macbeth encourages her husband, urging him to ignore the dangers and moral restrictions that stand in his way to seizing power:

Art thou afeard

To be the same in thine own act and valor

As thou art in desire? Wouldst thou have that

Which thou esteem 'st the ornament of life,

And live a coward in thine own esteem,

Letting "I dare not" wait upon "I would, "

Like the poor cat i' th' adage?"(Act 1, Scene 7)

Lady Macbeth takes active part in the scheme to murder

King Duncan by drugging his guards to sleep and planting bloodied daggers on their persons, rendering them suspect in committing her husband's crime. Following the murder, she tries to encourage Macbeth to suppress his thoughts on the terrible deed in order not to give himself away:

...Why, worthy thane,

You do unbend your noble strength to think

So brainsickly of things. Go get some water,

And wash this filthy witness from your hand

These deeds must not be thought

After these ways..." (Act 2, Scene 2)

How now, my lord! Why do you keep alone,

Of sorriest fancies your companions making,

Using those thoughts which should indeed have died

With them they think on? Things without all remedy

Should be without regard. What's done is done."(Act 3, Scene 2)

Later, Lady Macbeth notices signs of mental distress and weakness in her husband - fear, delusions and panic attacks and sets out to censure him:

"..This is the very painting of your fear.

This is the air-drawn dagger which you said

Led you to Duncan. Oh, these flaws and starts,

Impostors to true fear, would well become

A woman's story at a winter's fire,

Authorized by her grandam."(Act 3, scene 4)

It appears that of the two, it is Lady Macbeth who exhibits greater resilience. She is decisive and infused with motivation to achieve her end at any cost, dismissing the pressures of her superego by resorting to massive use of defence mechanisms, such as denial and intellectualization. These instruments, however, do not stand her in good stead for long. The audience is beginning to identify the turnaround occurring in the couple. Macbeth is starting to lose his ability for social judgment and his reality testing begins to falter. As regards his wife, a realization of the significance of their deed starts to sink in; her fortitude begins to weaken under the pressure of fear, and she develops dissociative and other symptoms characteristic of an obsessive-compulsive personality disorder:

Gentlewoman: Since his majesty went into the field, I have seen her rise from her bed, throw her nightgown upon her, unlock her closet, take forth paper, fold it, write upon 't, read it, afterwards seal it, and again return to bed; yet all this while in a most fast sleep.

Doctor: What is it she does now? Look, how she rubs her hands.

Gentlewoman: It is an accustomed action with her to seem thus washing her hands. I have known her continue in this a quarter of an hour.

Lady Macbeth: Yet here's a spot...Out, damned spot! Out, I say! ... What, will these hands ne'er be clean? ...Here's the smell of the blood still. All the perfumes of Arabia will not sweeten this little hand. Oh, Oh, Oh!

Doctor: What a sigh is there! The heart is sorely charged.

... Foul whisp'rings are abroad. Unnatural deeds

Do breed unnatural troubles. Infected minds

To their deaf pillows will discharge their secrets.

More needs she the divine than the physician. (Act 5, Scene 1)

Her state is unlike her husband's: as his mental condition deteriorates, he exhibits more immoral and destructive conduct with respect to himself and his surroundings:

Why should I play the Roman fool and die

On mine own sword? Whiles I see lives, the gashes

Do better upon them.

...Though Birnam Wood be come to Dunsinane,

And thou opposed, being of no woman born,

Yet I will try the last. Before my body

I throw my warlike shield. Lay on, Macduff,

And damned be him that first cries, "Hold, enough!"(Act 5, Scene 8)

Unlike Macbeth, who continues his journey of destruction until checked by external forces, Lady Macbeth withdraws into herself, seriously disheartened by the fact that her deeds have not lived up to her expectations: [14]

Naught's had, all's spent,

Where our desire is got without content.

'Tis safer to be that which we destroy

Than by destruction dwell in doubtful joy. "(Act 3, Scene 2)

Lady Macbeth's spirit is broken and she directs her aggression towards herself by an act of suicide, as reported by Malcolm:

.... and his fiendlike queen,

Who, as 'tis thought, by self and violent hands

Took off her life ..." (Act 5, Scene 8)

Thus ends a fatal partnership between an ambitious twosome whose conduct was regulated by their passion, paralysing their ability to act with discretion, with adaptiveness, and in accordance with social norms and morals, and barrelling them down a path of violence and destruction. 


\section{Prince Malcolm and the Triumph of Self-Awareness}

Prince Malcolm, the son of King Duncan and his rightful heir to the throne, occupies a relatively modest section in the play. Nevertheless, I see him as a highly significant figure from the viewpoint of a psychoanalytic understanding of the text and the actions of its central characters.

Symbolically, the murder of benevolent King Duncan by Macbeth and Macbeth's subsequent seizure of the throne violate the social balance in the kingdom and bring tragic results. A parallel may be seen in a condition where threatening and uncontrolled id content invading the personality can unsettle an individual's mental balance, disrupt his functioning, cause him untold suffering, and eventually destroy him [3].

With the termination of Macbeth's rule of tyranny and violence and his replacement by Malcolm, the lawful heir to the throne, natural order and justice are restored in the kingdom. This denouement can be likened to the role of therapeutic intervention in overcoming crises and restoring a balance between mental forces residing in different parts of an individual's personality: the id, ego and superego, according to the structural model [3]. This process and its results create a catharsis in the literature of tragedies, as stated by Dorothea Crook [5]) and as defined by Freud with respect to the psychoanalytic process of therapy [4].

In addition to its symbolic aspect, the figure of Malcolm and his statements express what is considered in psychoanalysis to be a state of self-awareness: a condition in which a person makes adaptive use of defence mechanisms, enabling him to bear with equanimity knowledge about instincts, urges and personal traits in himself that are uncomplimentary from the point of view of social codes and accepted moral judgment.

In a conversation with Macduff, Malcolm - who has experienced treason against his father by Macbeth - tests Macduff's loyalty by harshly criticizing his own personal deficiencies and observing Macduff's responses:

It is myself I mean, in whom I know

All the particulars of vice so grafted

That, when they shall be opened, black Macbeth

Will seem as pure as snow...

I grant him bloody,

Luxurious, avaricious, false, deceitful,

Sudden, malicious, smacking of every sin

That has a name. But there's no bottom, none,

In my voluptuousness. Your wives, your daughters,

Your matrons, and your maids could not fill up

The cistern of my lust, and my desire

All continent impediments would o'erbear

That did oppose my will.

... With this there grows

In my most ill-composed affection such

Stanchless avarice that, were I king,

I should cut off the nobles for their lands,

Desire his jewels and this other's house.
And my more-having would be as a sauce

To make me hunger more, that I should forge

Quarrels unjust against the good and loyal,

Destroying them for wealth. "(Act 4, Scene 3)

Another important reason for noting Malcolm's statements in the context of psychoanalytic theory is his positive attitude towards expressing emotions as an answer to the needs of the human mind and a way to maintain mental and physical health and adaptive behaviour. When Macduff receives news about the murder of his family by killers on behalf of Macbeth, he is consoled by Malcolm, who too has lost his father in similar tragic circumstances:

What, man! Ne'er pull your hat upon your brows.

Give sorrow words. The grief that does not speak

Whispers the o'erfraught heart and bids it break."(Act 4, Scene 3)

In thus speaking, Malcolm outlines the principle of emotional assistance through discourse some 400 years before Anna O (Bertha Pappenheim) coined the expression "talking cure" in connection with the first psychotherapeutic act in history (Freud, 2004).

\section{Conclusion}

In writing this article we have tried to show how powerful poesy in classic literature reflects basic clinical concepts and terms associated with traditional psychoanalytic theory. Support for the scientific teachings of Freud and his successors may be seen in many spheres of life, whether individual or social. One who is familiar with psychoanalytic precepts can identify their presence in books, pictures, films, and even in reality shows, newscasts and election campaign speeches by public figures.

We often see how unconscious forces of instinct lead individuals to make decisions that are fateful with respect to both themselves and society, and how rigid conceptions held stubbornly and non-adaptively can lead individuals, social groups and entire nations towards severe crises and suffering [10]. Artists and philosophers have for long attempted to understand the forces underlying personal conduct and come up with a recipe for easing human suffering. To our mind, answers are to be had in psychoanalytic theory and clinical practice, as they enable a person who thinks and behaves in accordance with psychoanalytic principles to gain control over his conduct with full awareness, and without pinning responsibility for a given condition on destiny or mysterious external forces.

\section{Compliance with Ethical Standards}

\section{Conflict of Interests}

The authors declare that they have no competing interests.

\section{Ethical Approval}

This article does not contain any studies with human participants performed by any of the authors. 


\section{References}

[1] Neuman, A. (2003). Points of Reference in Freud's Philosophy. In: Hatav (Ed.), Psychoanalysis - Theory and Practice (p. 163-181), Tel Aviv: Dionon Publishers.

[2] Freud, A. (1987). The Self and Defence Mechanisms (p. 2646). Tel Aviv: Dvir Publishers.

[3] Freud, Z. (1988). Totem, Taboo and Other Essays (p. 147185). Tel Aviv: Dvir Publishers.

[4] Freud, Z. \& Breuer, I. (2004). Research in Hysteria (p. 257275; 291-340). Zefat: Sefarim Publishers.

[5] Crook, D. (1971). Elements of Tragedy. Tel Aviv: Hakibbutz Hameuchad.

[6] Kristeva, J. (1991). Strangers to Ourselves. Columbia University Press.

[7] Shakespeare, W., (1989) Makbeth, Tel Aviv, Shoken Publishers.

[8] Churchil, C. J. (2015) "Is that all there is?" Time Guilt and
Melancholia in Sleep No More and Macbeth. Int. J. Appl. Psychoanal. Stud, 12 (2); 161-174.

[9] Sarge, C., (2019) Macbeth in a Psychoanalytic Perspective. The Hourglass Literature Blog. Ed. John Russel Brown. London Routledge Press.

[10] Russel, D., (1982) Hurt Minds, Focus on Macbeth. Ed. John Russel Brown. London Routledge Press.

[11] Holland, N., (1966) Psychoanalysis and shakespeare, N.Y, Mcgraw Hill Book Company.

[12] Waith, E., (1977) Manhood and Valor in Macbeth. Ed. Terrence Hakes, Englewood Cliff. N. J.

[13] Gruzina, R., (2005) Teaching William Shakespeare's Macbeth. Prestwick House Inc.

[14] Coriat, I., (1920) The Hysteria of Lady Macbeth. N.Y Moffat, Yard and Company.

[15] Kristova, J., (2017) 'I Have Supp'd Full with Horrors; a Kristevian Psychoanalytic Analysis of the Powers of horror in Macbeth. Published at the Conference Proceedings of the Kristeva 2017, Univ. of Pittsburgh Pennsylvania U.S.A. 